\title{
TRADITIONS AND MODERN TRENDS OF PROFESSIONAL TRAINING OF ARTISTS OF DECORATIVE AND APPLIED ART
}

\section{ТРАДИЦІЇ ТА СУЧАСНІ ТЕНДЕНЦІЇ ПРОФЕСІЙНОЇ ПІДГОТОВКИ ХУДОЖНИКІВ ДЕКОРАТИВНО-ПРИКЛАДНОГО МИСТЕЦТВА}

\author{
Yuliia POLTAVSKA, \\ Associate Professor \\ Юлія ПОЛТАВСЬКА, \\ доцент \\ mysec art@ukr.net \\ https://orcid.org/0000-0002-1041-8078
and Applied Art and Design by декоративно-прикладного
M. Boychuk
мистецтва і дизайну імені Михайла \\ Kyiv State Academy of Decorative Київська державна академія \\ Бойчука \\ 32, M. BoychukSt., Kyiv, $01103 \square$ вул. М. Бойчука, 32, Київ, 01103 \\ Original manuscript received: October 07, 2021 \\ Revised manuscript accepted: December 15, 2021
}

\begin{abstract}
The author of the article focuses on the fact that folk arts and crafts are an integral part of any culture, including the culture of the Ukrainian people. It contributes to the formation of artistic taste, education of love for the Motherland, pride in one's people, respect for age-old cultural traditions, awakens a sense of responsibility for the preservation of spiritual riches created by previous generations. The author also notes that decorative and applied art acquires special significance in modern socioeconomic circumstances. That is why the problem of finding new teaching methods in this area is extremely relevant. The author believes that at the present stage of development of pedagogical science it is necessary to apply methods of scientific research and research, use a systematic analysis of the problem of art education, historical analysis of domestic and foreign educational concepts in traditional arts and crafts, as well as the latest technologies - applied art. The author considers it important that the influence of mass culture affects the lives of Ukrainians, when forgeries of folk art acquire the character of outright "kitsch», and the mind and soul of modern boys and girls are practically devoid of national meaning, unable to distinguish good from evil and beautiful from ugly.

The article considers the issues of professional training of applied artists. Feature of traditional applied art, which reflects the movement of time and the general patterns of development of the world art process, influencing other areas of creative activity. The author of the article focuses on the fact that folk art occupies an important place in the system of means of forming creative activity of students, which integrates domestic, artistic and pedagogical traditions. The author emphasizes that modern teachers must adhere to a variety of tools when compiling curricula: apply research methods and research, use systematic analysis of the problem of art education, historical analysis of domestic and foreign educational concepts in the field of traditional arts and crafts; study of archival materials and documents, the state of professional training in other domestic and foreign educational institutions that train specialists in related specialties.
\end{abstract}


Key words: decorative and applied art, traditional, development, science, training, education, pedagogy, professional, history, people, technologies, directions.

Вступ. Сучасна вітчизняна педагогічна освіта шукає нові шляхи навчання та виховання молоді, серед яких концептуальні підходи, що ведуть до інтеграції певного масиву знань, який отримує студент в освітньому процесі. Але, без сумніву, варто пам'ятати, що професійне декоративно-прикладне мистецтво зберігає традиції нашого народу, несе в собі його генетичний код, традиційну культуру предків, національний характер. Саме тому важливе місце в системі засобів формування творчої активності студентів посідає народне мистецтво, що інтегрує в собі побутові, мистецькі та педагогічні традиції.

Залучення молоді до світу народної художньої культури через оволодіння професіями художників декоративно-прикладного мистецтва відкриває перед ними можливості самовиховання, самовдосконалення, усвідомлення приналежності до нашого народу, культура і мистецтво якого мають загальносвітове значення. Щоденно ми спостерігаємо за тим, як відбувається вплив масової культури на життя українців, коли підробки під твори народного мистецтва набувають характеру відвертого «кітчу», коли розум і душа сучасних юнаків і дівчат практично позбавлені національного змісту, не здатні відрізнити добро від зла і прекрасне від потворного.

Методи та методики дослідження. Надзвичайно важливо сорормулювати й теоретично обґрунтувати основні принципи формування саморозвитку творчої особистості як майбутнього художника декоративно-прикладного мистецтва, здатного творчо розвивати традиції народних художніх осередків і втілювати їх в художні твори декоративно-прикладного мистецтва, що відповідають сучасним соціально-економічним i естетичним вимогам. Також необхідно визначити комплекс навчальних завдань з професійної майстерності, що включає всі існуючі технології художніх напрямків; постійно вдосконалювати авторські програми за спеціальністю «Декоративноприкладне мистецтво».

Результати та дискусії. Особливість традиційного прикладного мистецтва в тому, що при всій своїй специфічності воно відображає рух часу і загальні закономірності розвитку світового художнього процесу, впливаючи на інші сфрери творчої діяльності. На українській художній культурі позначилися вікові традиції декоративно-ужиткового мистецтва, а для їі ментальності не були властивими індустріалізація та розповсюдження технічних фрорм. Народне декоративно-прикладне мистецтво України було головним чином мистецтвом селянським. Воно віками мало суто утилітарне призначення і складало частину хліборобського побуту (ткацтво, вишивка, посуд, реманент, розписи хат, писанок тощо). Паралельно з селянським мистецтвом співіснували цехове, монастирське, мануфактурне ремесло, зароджувалася фабрична художня промисловість. Кожен з напрямків мав свою систему 
організації виробництва, специфічні техніко-мистецькі засоби, іконографічні та стилістичні відмінності. Але саме в так званому селянському декоративно-прикладному мистецтві найорганічніше виявились етнічні риси.

Зібраний у XIX ст. образотворчий матеріал вражає емоційною виразністю, естетичною досконалістю, регіонально-стилістичним розмаїттям, у той час, коли українське за духом професійне мистецтво перебувало в досить занедбаному стані. В Україні художня освіта сформувалася на кілька століть пізніше, ніж у Західній і Центральній Європі, через кілька десятиріч після заснування таких установ у столицях держав, до складу яких входила територія України. Ці обставини поділили українське мистецтво на «традиційне», що побутувало в соціальних низах, i «вчене», що прищеплювалося вихованцям академій у Петербурзі, Кракові, Мюнхені, Відні й інших центрах і розвивалося паралельно з народним.

Перші спроби керівництва навчально-творчими процесами в мистецтві зробила Комісія з питань промислів, заснована у Львові ще 1877 року. Було створено курси, пересувні майстерні та художньо-промислові школи, які готували спеціалістів-виконавців та інструкторів для різних видів художніх промислів. Такі навчальні заклади були організовані в Риманові (1871), Львові (1875), Закопаному (1876), Станіславі (1884), Чернівцях (1896), Коломиї (1894), Яворові (1896), Старому Косові (1923, школа Девдюка). Розвитку і популяризації народного мистецтва сприяли діячі української культури М. Біляшівський, Д. Щербаківський, Х. Вовк, С. Таранушенко. Актуальними і в наш час $є$ слова С. Таранушенка, який ще 1922 року писав: «Для того, щоб наші вироби були і справді художніми, необхідно залучити в цю роботу справжніх художників як освічених професіоналів, так і художників з народу».

Питання фахової підготовки художників-прикладників хвилювало й організаторів художньо-виробничої діяльності народних промислів. Виходячи з особистого досвіду роботи в художніх промислах, В. Парахін вказував на хибність існуючої практики навчання молоді народного декоративно-прикладного мистецтва: «Наша здібна молодь йде до училищ «народного» і ужиткового мистецтва, де орієнтований на академізм навчальний процес робить із юнаків і дівчат імітаторів народної творчості». Він застерігав, що академічні принципи навчання не сумісні з народними, адже «народний майстер не готується школою, а вирощується всією наповненістю місцевого культурного середовища».

Неприйняття комуністичною радянською ідеологією будь-чого, пов'язаного з глибинною етнічністю, релігією, потойбічністю, духовністю, інтелектуалізмом, виключало навіть постановку питання про приховану багатошарову символіку форм і осмислення декоративно-прикладного мистецтва. Ідеологія, що панувала на той час, зумовила «підтягування» орна-ментально-умовного народного декоративного мистецтва до рівня реалістично-зображувального станкового. Масовій свідомості українців цілеспрямовано прищеплювалась аксіома, що селянство $є$ не тільки носієм, а й основним творцем ледь не всіх видів традиційного мистецтва, на 
противагу «новаційній» культурі міста. У пропагандистських виданнях того часу можна прочитати такі слова: «Канули в минуле важкі роки для українського народу. Квітне радянська Україна під великим прапором Леніна-Сталіна. Не на гнобителів-панів, а на себе, на трудящих виробляє зараз майстер кращі свої твори. Килими і плахти, тканини і сорочки, рушники і покривала - з візерунками українських вишивок, орнаментом прикрашають дівчат, жінок, дітей, молодих і старих людей - громадян радянської України. Свої величезні таланти український народ розвиває і вирощує з невиданою блискучістю» .

Дисонансом звучали вислови окремих представників старої «буржуазної» школи, які вбачали в народному мистецтві не стільки творчість соціальних низів, скільки релікти «високої» архаїки (Павлуцький, 1927), вказували, що глухі місцини є передусім «інтерпретаторами», «консервантами», «ретрансляторами» орнаментного мистецтва, його ж генератори - жваві роздоріжжя, багатолюдні міста, межі культурних ландшафттів і зони міжетнічних контактів (Антонович, 1940-1993; Біляшівський, Зеленін, Колос).

На зламі XIX і XX століть настав час для плідного синтезу обох напрямків українського мистецтва. Це явище пов'язане із діяльністю видатного художника, виняткової постаті українського авангарду - Михайла Бойчука. Основою творчості митців «Розстріляного Відродження» було бажання повернутися до втрачених образів вічного. Та невелика кількість збережених робіт художників-бойчукістів свідчить про силу та переконливість, якими вони виражали ментальність українського народу, створювали яскраву національну художню школу, взаємопов'язану 3 монументальним і станковим живописом, графрікою, декоративноприкладним мистецтвом, у розвиток якого зробили великий внесок.

М. Бойчук та його учні були творцями тієї національної традиції, де ідеї сучасного мистецтва спиралися на багатовіковий досвід народної художньої творчості. Вони прагнули створити синтетичні форми, де розвинена традиція монументального живопису Візантії, Київської Русі та Проторенесансу поєднувалася з багатовіковим досвідом народних майстрів України. Ідея високого світового мистецтва розглядалася ними в умовах найглибшого розкриття національної школи. У період панування соціалістичного реалізму художня педагогіка передбачала фрормування ремісничих академічних навичок i лише пізніше дозволявся процес формування творчості та знайомство 3 матеріалами й техніками. І, напевно, не мала б наша національна культура багатьох самобутніх талановитих майстрів, відомих усьому світу, - Т. Пати, К. Білокур, династії Шкрібляків-Корпанюків, П. Хоми, М. Приймаченко, якби вони пройшли через згадану систему навчання.

На сучасному етапі суспільного життя, коли головним напрямом культурного й національного виховання $€$ звернення до людини, до її духовного розвитку та становлення, традиції національного мистецтва сприяють досягненню високого розвитку духовного світу та розумінню культури. Це $є$ однією з умов фрормування етнокультури студентів, 
організації наукового та навчально-виховного процесу в КДАДПМД імені М. Бойчука з підготовки фахівців, звернення під час навчання до духовних коренів народного мистецтва, його зв'язків з побутом і фольклором.

Основними напрямками формування художньої культури студентів можна вважати: передачу знань про витоки, художні та виконавські традиції народного декоративно-прикладного мистецтва; формування уявлень про декоративну культуру, що передбачають гармонійне та цілісне вирішення мистецького твору, забезпечення виконавської майстерності, що включає засвоєння певних художніх i технологічних прийомів, необхідних саме в декоративно-прикладному мистецтві. На жаль, сьогодні порушений механізм передачі цінностей ідей, переконань, поглядів, життєвих принципів, ідеалів, а існуючі освітні напрямки в досліджуваній галузі недостатньо ефективні. Варто пам'ятати, що духовні ідеали не можна отримати таким же шляхом, яким отримують знання. Передача цінностей повинна здійснюватися в процесі духовного діалогу, який принципово відрізняється від спілкування лише на інформаційному рівні. Ця проблема залишається актуальною для сучасної мистецької освіти.

Творче освоєння традиційного декоративно-прикладного мистецтва як навчальних дисциплін в вищих мистецьких навчальних закладах досягає своєї мети, коли: художньо-педагогічний процес буде здійснюватися в єдності принципів загальної дидактики та педагогіки мистецтва; зміст художньої освіти буде структуровано відповідно до чіткої послідовності та логіки навчальних завдань, їх поглибленим змістом, що сприяють зростанню художньо-естетичного рівня студентів, їх професійної майстерності; в освітній процес мають бути впроваджені методи активізації пізнавальної діяльності студентів в поєднанні з конкретною професійною спрямованістю різних видів декоративно-прикладного мистецтва: художньої кераміки, розпису, художнього металу та дерева, ткацтва, вишивки тощо.

Сучасні педагоги мають притримуватися найрізноманітніших засобів під час складання навчальних програм: застосовувати методи наукового пошуку і дослідження, використовувати системний аналіз проблеми художньої освіти, історичний аналіз вітчизняних і зарубіжних освітніх концепцій у галузі традиційного декоративно-прикладного мистецтва; вивчення архівних матеріалів і документів, стану професійної підготовки в інших вітчизняних та закордонних закладах освіти, що готують фахівців споріднених спеціальностей. Не менш важливо проводити аналіз діяльності випускників закладів освіти декоративно-прикладного мистецтва, слідкувати за сучасними тенденціями та технологіями.

Висновки. Ось чому якість підготовки фахівців у галузі народного декоративно-прикладного мистецтва на сучасному етапі має становити значний державний інтерес, адже від цього залежить естетичний рівень майбутніх художників-прикладників, їх майбутнє, розвиток споживчого інтересу до виробів. Формування художньої культури студентів засобами декоративно-прикладного мистецтва буде здійснюватися більш ефективно в координатах спеціально розробленої і експериментально 
перевіреної системи навчання, що базується на освоєнні художньообразної мови декоративного мистецтва. Таким чином, варто зазначити, що декоративно-прикладне мистецтво як частина сучасної культури бере активну участь в естетичному формуванні художнього смаку особистості, вихованні гордості за власний народ, поваги до вікових традицій і відповідальності за духовне багатство, створене попередніми поколіннями. А сучасна педагогічна наука володіє необхідними концепціями для постановки i розв'язання питань, пов'язаних із забезпеченням процесу навчання майбутніх художників декоративноприкладного мистецтва, ураховуючи кращі надбання минулого.

\section{Література}

1. Антонович Є. А., Захарчук-Чугай Р. В., Станкевич М. Є. Декоративноприкладне мистецтво. Львів : Світ, 1993. 272 с.

2. Бабіченко Д. Художні промисли України. Образотворче мистецтво. 1979. № 1. C. 16-17.

3. Бєлкіна Ф. Вікно в минуле. Мистецтво і освіта. 2000. № 1. С. 7-11.

4. Вступна стаття. Антологія «Вісник археології, мистецтва, культурної антропологї̈». 2003. № 10-12. С. 6.

5. Голубець Л. А. У пошуку нетрадиційних форм. Львів, 1988.

6. Есте. Українські кустарні вироби. Вісті Всеукраїнського виконавчого комітету. VI, 13. Харків, 1922. № 127.

7. Короткий довідник виставки українського народного мистецтва (1936).

8. Лащук Ю. Свобода духу: що це - пізнання і засвоєння чи імітація і загибель? Артанія. 1996. № 2.

9. Парахін В. Народне мистецтво завтра: відродження чи імітація? Образотворче мистецтво. 1996. № 1.

10. Соколюк Л. Графріка Бойчукістів. Харків-Нью-Йорк, 2002.

\section{References}

Antonovich, E.A., Zakharchuk-Chugai, R.V., Stankevich, M.E. (1993). Dekoratyvno-prykladne mystetstvo [Arts and crafts]. Lviv : Svit. [in Ukrainian].

Babichenko, D. (1979). Khudozhni promysly Ukrayiny [Arts and crafts of Ukraine]. Obrazotvorche mystetstvo - Fine Arts, 1, 16-17 [in Ukrainian].

Belkina, F. (2000). Vikno v mynule [Window to the past]. Mystetstvo i osvita Art and Education, 1, 7-11 [in Ukrainian].

Vstupna stattya [Introductory article] (2003). Antolohiya «Visnyk arkheolohiyi, mystetstva, kul'turnoyi antropolohiyi» - Anthology «Bulletin of archeology, art, cultural anthropology», 10-12, 6 [in Ukrainian].

Golubets, L.A. (1988). U poshuku netradytsiynykh form [In search of nontraditional forms]. Lviv [in Ukrainian].

Este. Ukrayins'ki kustarni vyroby (1922). [Yes. Ukrainian handicrafts]. Visti Vseukrayins'koho vykonavchoho komitetu - Bulletin of the All-Ukrainian Executive Committee. VI, 13. Kharkiv, №127 [in Ukrainian].

Korotkyy dovidnyk vystavky ukrayins'koho narodnoho mystetstva [Short reference book of the exhibition of Ukrainian folk art] (1936) [in Ukrainian].

Lashchuk, Y. (1996). Svoboda dukhu: shcho tse - piznannya i zasvoyennya chy imitatsiya i zahybel'? [Freedom of spirit: what is it - cognition and assimilation or imitation and death?]. Artaniya - Artania, 1996, 2 [in Ukrainian]. 
Parakhin, V. (1996). Narodne mystetstvo zavtra: vidrodzhennya chy imitatsiya? [Folk art tomorrow: revival or imitation?]. Obrazotvorche mystetstvo - Fine Arts, 1996, 1 [in Ukrainian].

Sokolyuk, L. (2002). Hrafika Boychukistiv [Graphics Boychukists]. KharkivNew York [in Ukrainian].

\section{АНОТАЦІЯ}

Автор статті зосереджує увагу на тому, що народне декоративноприкладне мистецтво є невід'ємною частиною будь-якої культури, у тому числі і культури українського народу. Воно сприяє формуванню художнього смаку, вихованню любові до Батьківщини, гордості за свій народ, поваги до вікових культурних традицій; пробуджує почуття відповідальності за збереження духовних багатств, створених попередніми поколіннями. Також автор зазначає, що особливу значущість декоративно-прикладне мистецтво набуває в сучасних соціально-економічних обставинах. Саме тому проблема пошуків нових методів навчання в цій галузі $є$ надзвичайно актуальною. Автор вважає, що на сучасному етапі розвитку педагогічної науки варто застосовувати методи наукового пошуку і дослідження, використовувати системний аналіз проблеми художньої освіти, історичний аналіз вітчизняних $i$ зарубіжних освітніх концепцій у галузі традиційного декоративно-прикладного мистецтва, а також новітні технології, що сприяють розвиткові напрямів декоративно-прикладного мистецтва. Автор вважає важливим те, що вплив масової культури відбивається на житті українців, коли підробки під твори народного мистецтва набувають характеру відвертого «кітчу», а розум $i$ душа сучасних юнаків і дівчат практично позбавлені національного змісту, не здатні відрізнити добро від зла і прекрасне від потворного.

у статті розглядаються питання фрахової підготовки художниківприкладників. Особливість традиційного прикладного мистецтва, що відображає рух часу і загальні закономірності розвитку світового художнього процесу, впливаючи на інші сфери творчої діяльності. Автор статті особливу увагу зосереджує на тому, що народне мистецтво посідає важливе місце в системі засобів формування творчої активності студентів, що інтегрує в собі побутові, мистецькі та педагогічні традиції. Автор наголошує, що сучасні педагоги мають притримуватися найрізноманітніших засобів під час складання навчальних програм: застосовувати методи наукового пошуку і дослідження, використовувати системний аналіз проблеми художньої освіти, історичний аналіз вітчизняних $і$ зарубіжних освітніх концепцій у галузі традиційного декоративно-прикладного мистецтва; вивчення архівних матеріалів $i$ документів, стану професійної підготовки в інших вітчизняних та закордонних навчальних закладах, що готують фахівців споріднених спеціальностей.

Ключові слова: декоративно-прикладне мистецтво, традиційне, розвиток, наука, навчання, освіта, педагогіка, профресійне, історія, технології, напрямки. 